\title{
THE MYTH OF THE EMPTY TERRITORY: THE TRAGEDY OF THE CHAGOS ISLANDERS
}

\author{
Esther Pujolràs-Noguer \& Felicity Hand \\ Universitat de Lleida \& Universitat Autònoma de Barcelona
}

\begin{abstract}
In this article we outline the tragedy of the Chagos Islanders forcibly evicted from their homeland to make way for an American military base. A new colony was invented, the British Indian Ocean Territory, which would be declared a marine reserve in 2010. The British have refused to allow the Chagossians the right to return to their homelands not to protect the environment, but rather to safeguard the political agreement based on economic and military imperialism. Therefore this community has been condemned to historical erasure as their stories are imbricated in the official narration of an empty territory. To prevent the plight of the Chagossians from falling into oblivion, we organized a creative writing workshop with members of the community in order to grant visibility to the Chagossian fight for identity and recognition.
\end{abstract}

Keywords: Chagos, Imperialism, Creative Writing, Identity, Memory.

\section{EL MITO DEL TERRITORIO VACÍO: \\ LA TRAGEDIA DE LOS HABITANTES DE LAS ISLAS CHAGOS}

\section{RESUMEN}

En este artículo describimos la tragedia de los habitantes de las islas Chagos, los cuales fueron desahuciados de su tierra natal para que los americanos pudieran construir una base militar. Para ello fue necesario inventar una nueva colonia, British Indian Ocean Territory, que fue declarada reserva marina en el año 2010. Los británicos han denegado a los Chagosianos el derecho a regresar a su tierra natal no por razones ecológicas de protección del medio ambiente sino para preservar un acuerdo político basado en un imperialismo económico y militar. Así pues, la historia oficial de esta comunidad está unida a lo que denominamos la narración del territorio vacío, una narración perversa que los condena a una invisibilidad perenne. Para impedir que su tragedia caiga en el olvido, organizamos un taller de escritura creativa con miembros de la comunidad para así dar visibilidad a su lucha por ser reconocidos. Palabras Clave: Chagos, imperialismo, escritura creativa, identidad, memoria. 


\section{Western Indian Ocean}

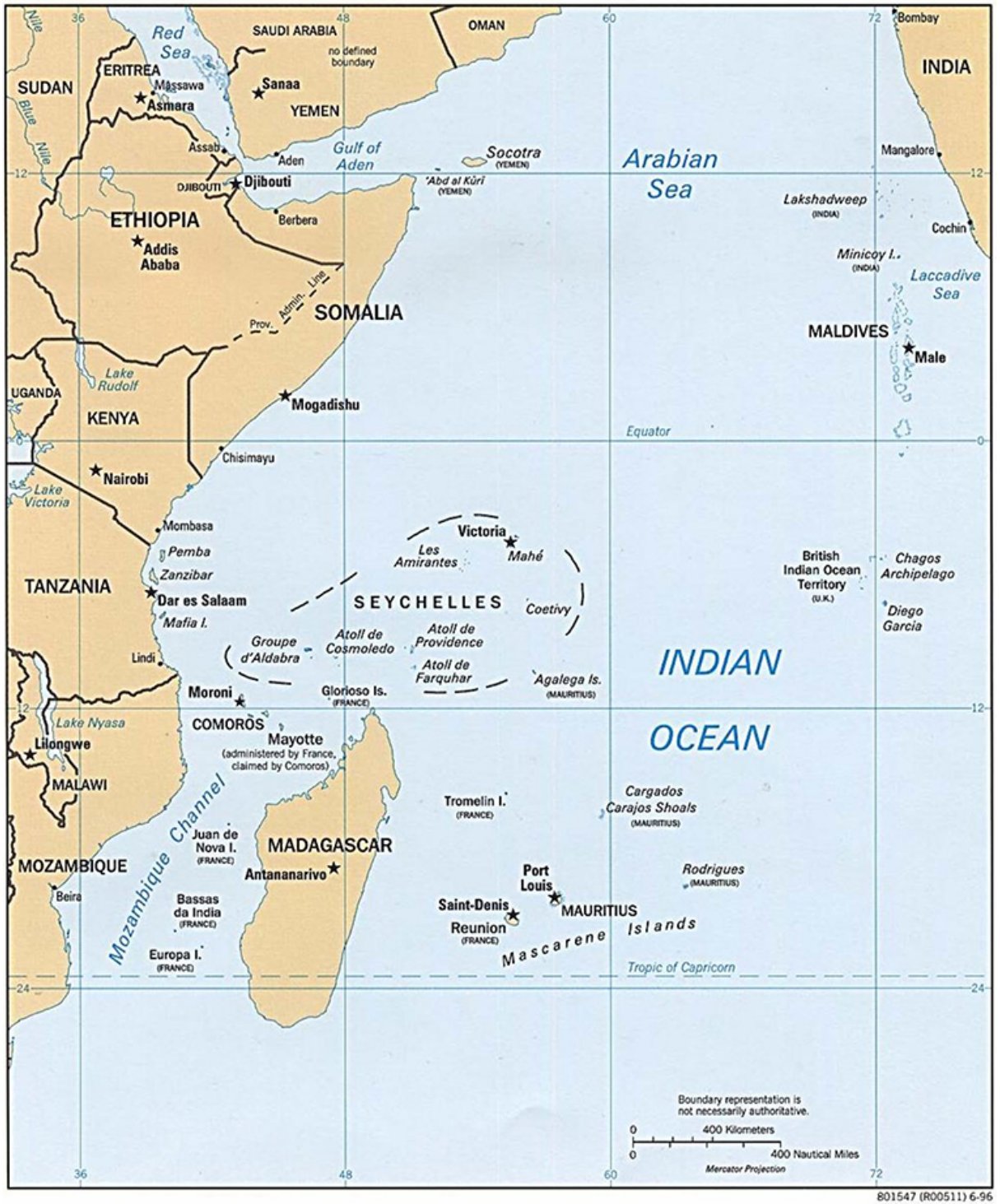




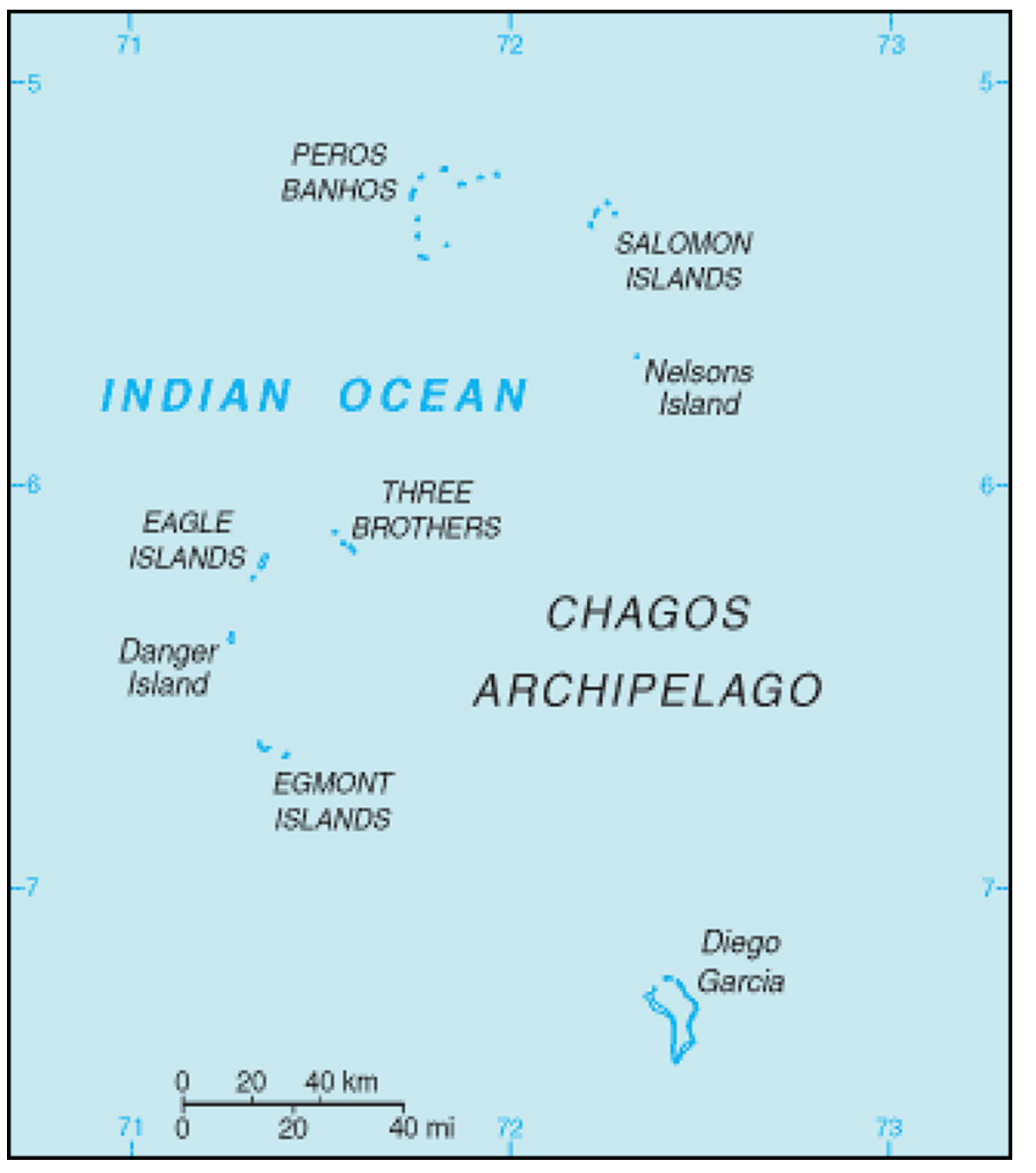


Mo pa pou bliye

Zame mo pa pou bliye, mo mama

Mo pa pou bliye

Laba mo'nn kit dan simitier

Mo pa pu bliye

Zame m opa pou bliye mo fami

Soufle trwa kou

Mauritius inn zet nou dan Moris

Li bien foupamal

Li bien never mind misie-la

Li bien foupamal

Kant mem nou pena boulo ${ }^{1}$

\section{WAS THIRTEEN}

I was thirteen

Since I was thirteen in Chagos

I was thirteen

I held the coconut knife in my hand

The British came

The British masters landed in Chagos

The British came

You, British, took our bread from our mouths

I won't forget

I'll never forget, my mother

I won't forget

I left her over there in the cemetery

I won't forget

I'll never forget, oh my family,

It blew thrice

The Mauritius threw us overboard in Mauritius

He doesn't care

$\mathrm{He}$ is a "never mind" master

He just doesn't care

Even if we are jobless

1 Group Tanbour Chagos. Leritaz Kiltir Chagossien. 2018. Chagos Refugees Group and University of Edinburgh. As stated in the back cover, the album is a tribute to Chagossians: "This album pays tribute to Chagossians who sang these (and other) songs on Chagos, and is dedicated to all Chagossians and their supporters." 
"Mo ti ena 13 an," is the first song of the total 12 songs that form the record Group Tanbour Chagos. Leritaz Kiltir Chagossien sung in Kreol, the language of the Chagossian Islanders, to the rhythm of sega, a syncretic musical genre forged within the colonial plantations of Indian Ocean islands. Echoing the plea of their enslaved African ancestors, sega song lyrics depict episodes of ordinary life while infusing them with the spirit of dissent of protest songs. The reason why we have chosen this particular song to start our article on the Chagos Islanders is because "Mo ti ena 13 an" (When I was thirteen) captures the fateful moment when, as Chagossians put it, "the land was sold" 2 and they were therefore displaced from their homeland and literally thrown in Mauritius. The song works within a remembrance framework whereby an adult Chagossian recalls the instant in which she ${ }^{3}$, alongside her other fellow Chagossians, is ruthlessly uprooted and thus, her song emerges as a powerful remonstrance of resilience, a resisting performance against oblivion. This article stems from our desire to contribute to remember and make visible the tragedy of the Chagos Islanders in an attempt to legitimize academically their history of displacement and hence position it as a crucial instantiation of contemporary colonialism. The first section of the article -The Chagos Islanders. Victims of a Ruthless Kidnapping-will be devoted to outlining the colonial history of dispossession of the Chagos Islanders whereas the second section -Writing Myth and Memory to Fight Cultural Injustice Against Chagossians- will present and discuss a performance against oblivion, namely the creative writing workshop that we, together with Dr Farhad Khoyratty from the University of Mauritius, organized as a means to make the tragedy of the displaced islanders visible.

\section{THE CHAGOS ISLANDERS. VICTIMS OF A RUTHLESS KIDNAPPING}

The tragedy of the Chagos Islanders is the 50-year-old story of a displaced people, forcibly evicted from their homeland and resettled in Mauritius or the UK where many finally migrated. The Chagos Islands, of which Diego García was the most populated, were handed over to the Americans by the British to be used as a military base. The Chagos formed part of what was then the British colony of Mauritius, which gained its independence in 1968. The two thousand islanders were left without a home from 1967 to 1973, the year the last ship, the Nordvaer brought the last Chagossians to Mauritius. The ruthless handling of the Chagossian people, dispensable objects that had to be removed to make way for the military use of the island of Diego Garcia, is poles apart from the protection and support received

2 "When the land was sold" is the sentence that the participants in our creative writing workshop repetitively used to refer to that original moment of displacement. Incidentally, this is the title we have chosen for our blog on the Chagos Islanders.

${ }^{3}$ The singer's name is Mary Joyce Mercida and this explains the use of the female pronoun "she". 
by the Falkland Islanders during the conflict with Argentina in 1981. The British declared the area a marine reserve in 2010, but their refusal to allow the Chagossians the right to return to their homelands is not to protect the environment, but rather to safeguard the political agreement based on economic and military imperialism.

The Chagos Islands were originally populated with slaves from coastal East Africa and Madagascar who arrived there via Mauritius, but Mauritius itself has no indigenous population as everybody there was a migrant, either voluntary or enforced. By the mid-twentieth century Chagos had a population of approximately 2000 , most working in the coconut plantations, producing copra and coconut oil for export (Jeffery 2006, 298). In 1965, following independence negotiations with Mauritian politicians, the UK government excised Chagos from colonial Mauritius to form part of the new British Indian Ocean Territory. In 1968 Britain began illegal and secret removal of the population of the Chagos Islands following an agreement in 1966 to lease the islands to the US so that Diego Garcia would become available for a US military base. In this way the Whitehall conspiracy that contended that there were no indigenous inhabitants was formulated. At the request of the US government, the UK government had literally depopulated the entire archipelago by 1973 , first by restricting the importation of supplies and preventing the return of Islanders who had gone to Mauritius for medical treatment, and later by forcibly removing the remaining Islanders and sending them to Mauritius and the Seychelles. In other words, the British government saw fit to invent a new colony, the British Indian Ocean Territory (BIOT), just to justify the detachment of part of what was in fact the colony of Mauritius. As Mauritian historian Jocelyn Chan Low pertinently asks: "Why a new colony in the Indian Ocean at a time when the British seemed bent on getting rid of the remaining dust of empire?" (Chan Low 107).

The Chagos Islands and their inhabitants were fairly isolated from the outside world but before the creation of BIOT "the Indian Ocean connected the Chagos and Mauritius on a regular but somewhat infrequent basis" (Johannessen 2018, 268). It is undeniable that the sole purpose of creating BIOT was to kick the Chagossians out. They were not regarded as permanent inhabitants of the islands, but rather as a so-called "floating population," that is temporary workers or, imported labourers (Johannessen 2018, 279). This is of course untrue as Chagossians had been living on the islands since the early $19^{\text {th }}$ century, proof of which are the numerous graves of people dating back several generations. Instead of acknowledging their right to the land, the British showed an imperious attitude of contempt towards the islanders by maintaining the fiction that they didn't exist as political subjects. According to the British and the Americans, there was no functioning civilization on the islands so the people were expendable, in other words, their presence was regarded as a trivial detail. This is disturbingly obvious in John Pilger's moving documentary Stealing a Nation (2004), where he argues that the recuperation of the Chagossians' right to their land is a quest for justice.

The newly independent state of Mauritius does not come out of this issue completely blameless as it decided not to put forth its claims over the Chagos and not to raise the issue at the United Nations (Chan Low 120). Chan Low goes on to argue that if Sir Seewoosagur Ramgoolam -the first Prime Minister of 
independent Mauritius- finally conceded on Diego Garcia it was because he had become convinced -the British having manoeuvred brilliantly to convince himthat if he proved conciliatory on the excision of the Chagos Archipelago, the British government would finally decide in favour of independence for Mauritius at the close of the Constitutional Conference in 1965 (Chan Low 118; Jeffery 2006, 304). It is only in recent years that Mauritius is claiming sovereignty over the islands that it happily signed away. The inclusion of the Chagos Archipelago -and the intervening waters- as part of Mauritian territory would increase its size and importance on the world stage. Mauritius failed to act in accordance with the basic tenets of humanity as the deported Chagossians were left to their own devices once they were disembarked in Port Louis and relegated to the lowest position in society. Their living conditions were -and many still are- precarious and unsanitary. ${ }^{4}$ It is true that the years leading up to and immediately after the independence of Mauritius were highly volatile with interethnic strife, rising unemployment and a housing shortage threatening the viability of the new state (Jeffery 2010,1102) which was not the ideal scenario for the integration of the new migrants. Over the years various Chagossian groups in Mauritius have campaigned for fair compensation and the right to return to Chagos. Their records document one thousand surviving islanders plus approximately 4500 of their second generation offspring. The Chagossians won limited financial compensation from the UK government in 1978 and 1982 but lost a legal claim for further compensation in 2003 (Jeffery 2007, 963). A judicial review in the name of the Chagos Refugees Group leader, Olivier Bancoult, concluded in 2000 that the depopulation of Chagos had been unlawful since it was contrary to the laws of the territory. In response, the UK government used the royal prerogative to impose a new immigration ordinance in 2004 preventing Chagossians from entering the territory so the people would be banned forever from returning to their homeland. Olivier Bancoult's legal team won a judicial review of this latter legislation in 2006 -a shaming rebuke from the High Court which ruled in favour of the Islanders. The UK government appealed unsuccessfully in the Court of Appeal in 2007, but won its final appeal in the House of Lords in 2008. ${ }^{5}$ It is beyond the scope of this article to delve further into the legal proceedings and the political tug-of-war over sovereignty among the Chagossian communities in Mauritius and in the UK but suffice it to say that certain groups would be in favour of the Chagos returning to Mauritius while others are claiming for total independence. ${ }^{6}$ The legal proceedings are still ongoing but despite all these setbacks, the Chagos Refugees Group remains committed to seeking the right to resettle Chagos. The 2019 United Nations Resolution has - unsuccessfully- demanded the UK return control of the Chagos Islands to Mauritius but despite all these setbacks, the Chagos Refugees Group remains committed to seeking the right to resettle Chagos.

\footnotetext{
${ }^{4}$ See Jeffery \& Vine 2011. 98-100 and Ravi 2010. 345.

5 See Stephen Allen, 2014 chapters 1 \& 2; Johannessen 2010 72; Lobo 2016. 13.

${ }^{6}$ See de l'Estrac, 2011 chapter XIII for a detailed discussion on the sovereignty issue.
} 
In order to justify the creation of the marine protected area (MPA), the British Foreign Office had continually asserted that it was impossible for the Chagossians to return to their homes and to this end they conducted a feasibility study in which it was claimed that in the longer term life would be precarious and human interaction on global warming would be counterproductive. Therefore, the question arises as to the pollution caused by the 4000 US servicemen and women and the civilian contractors who work on Diego Garcia, the largest American military base outside the US, and the immense environmental damage caused by the building of the base (Sand 2009, 120). The Americans are keen to extend the 50-year lease and each side, the US and the British both claim that it is for the other side to decide the feasibility of a return of the Chagossians thus washing their hands of any responsibility (Curtis 2007). It is true that a select group of Chagossians was permitted to visit the islands in 2006 -what was regarded as a pilgrimage as opposed to a humanitarian visit for the islanders- but the stay on Diego Garcia was much more controlled as "all cameras were confiscated and not redistributed until after visitors left the military area" (Johannessen 2011, 204).

Time is clearly not on the side of the Chagossians. When the area was declared a marine reserve in 2010 , the islanders claimed the project to be a ploy to block their return, as it would make it impossible for them to live there since it would ban fishing, their main livelihood (Lobo 13-14; Rincon 2010). As far as the rationale for the creation of the marine reserve area is concerned, the recent leaking of a series of documents that are US state department cables recording private meetings between Foreign Office officials and their American counterparts are exceedingly revealing.

[Her Majesty's Government] would like to establish a "marine park" or "reserve" providing comprehensive environmental protection to the reefs and waters of the British Indian Ocean Territory (BIOT), a senior Foreign and Commonwealth Office (FCO) official informed Polcouns [Political Counsellor] on May 12. The official insisted that the establishment of a marine park - the world's largest would in no way impinge on USG use of the BIOT, including Diego Garcia, for military purposes. He agreed that the UK and US should carefully negotiate the details of the marine reserve to assure that US interests were safeguarded and the strategic value of BIOT was upheld. He said that the BIOT's former inhabitants would find it difficult, if not impossible, to pursue their claim for resettlement on the islands if the entire Chagos Archipelago were a marine reserve (Curtis, website).

The conclusions of Colin Roberts, the Foreign and Commonwealth Office's (FCO) Director, Overseas Territories are equally significant:

According to the HMG's current thinking on a reserve, there would be "no human footprints" or "Man Fridays" on the BIOT's uninhabited islands. [Roberts] asserted that establishing a marine park would, in effect, put paid to resettlement claims of the archipelago's former residents. Responding to Polcouns' observation that the advocates of Chagossian resettlement continue to vigorously press their case, Roberts opined that the UK's "environmental lobby is far more powerful than the Chagossians' advocates" (Curtis, website; italics in original). 
The decision to establish a military base on Diego Garcia was clearly part of the United States' wide global military strategy as its "V-shaped atoll provided a perfect maritime harbour right in the middle of the Indian Ocean" (Johannessen 2018, 269).

The case oflfor the Chagos Islands posits a challenge to studies of transnationalism and globalization inasmuch as it stands as a pungent example of the linguistic manipulation of power discourses. A straightforward military occupation is legally sanctioned by resorting to an environment-friendly-constructed jargon that presents the Chagos Islands as a site to be protected against the "destructive" actions of their native inhabitants. There is a further challenge to be considered in the case of / for the Chagos Islands and that is a challenge addressed to, in Davis and Todd's words, "the bounds and the legitimacy of the nation-state structure itself" (Davis and Todd 774). During British colonial times, the Chagos Islands territory was envisioned as an integral part of Mauritius but upon the advent of independence, as we have discussed elsewhere, the BIOT was created so that this territory could easily become American territory. This political transaction between the UK and the US left the Chagos Islanders in a state of utter powerlessness which resulted in their homeland displacement and abandonment in Mauritius. Strictly speaking, the Chagos Islanders were not Mauritian citizens. The Chagos Islands fell prey to British, American and Mauritian national interests and as such they materialize as a stalwart albeit distressing example of the global essence of colonial dispossession.

\section{WRITING MYTH AND MEMORY TO FIGHT CULTURAL INJUSTICE AGAINST THE CHAGOSSIANS}

In an essay entitled "Reflections on Exile," Edward Said offers one of the most pungent definitions of exile. Exile, he asserts, "is strangely compelling to think about but terrible to experience," (Said 173) and, he continues, "it is the unhealable rift forced between a human being and a native place, between the self and its true home: its essential sadness can never be surmounted" (Said 173). Exile is thus captured as an existential malaise that impinges sorely on the lives of those who are deracinated and literally left without a home. This is indeed the tragedy enveloping the Chagossian experience, a tragedy that is persistently nurtured by fragmentation and loss and which, to our mind, should be inscribed within the literature of trauma studies.

The trauma of exiles is, at least in the modern era, conspicuously entrenched in the trauma of colonization and, in this respect, once again, the case of the Chagos Islands is an excruciatingly painful illustration of the ruthless machinations of power forces and, at the same time, it also provides us with a unique insight into the ironies and ambivalences of the colonial/imperialistic enterprise: amid the imminent independence of former colonies, a new "colony", the BIOT, is created so as to preserve British and American interests in the area. In a cynical twist, a discourse of environmental protection is generated to justify their purely colonialist bias. As postcolonial scholars, it was in their stature as colonial victims that we were drawn 
towards the Chagos Islanders and, it is from our position as what we like to term "literature practitioners," rather than literary critics, that we have approached an examination of the tragedy of the Chagossians via a creative writing methodology. In August 2019, with the logistical support of the Chagos Refugees Group, which promotes and preserves the culture and traditions of the Chagos Archipelago, together with Dr. Farhad Khoyratty from the University of Mauritius, we organized a creative writing workshop, entitled "Writing Myth and Memory to Fight Cultural Injustice Against Chagossians," which aimed to make the tragedy of the displaced islanders visible. Naturally, the question that ensues is the following: what can a creative writing workshop offer that is intrinsically different to other methodologies? In order to answer this question, we will need first to elucidate what the myth of the empty territory entails and to what extent this myth can be liberating or, on the contrary, enslaving.

The horror of a fragmented subjectivity is tacitly counterbalanced by the creation of what Said names a "reassembled identity" which, through the workings of the imagination, fabricates a desired homeland and thus, discursively fills up the void of the loss produced by forced displacement. In other words, the exiles' broken lives are reconstructed, albeit moderately, by re-imagining a homeland and, from this perspective, we could infer that this creation process is, in fact, a survival strategy that allows exiled communities to lay claim to an origin, or, to be more precise, to an original home. The ethos of exile is punctuated by a "discontinuous state of being" (Said 177) and precisely because they "are cut off from their roots, their land, their past" (Said 177), they obstinately cultivate a desire for wholeness expressed as a myth of origins. If, as Simone Weil expressed, "to be rooted is perhaps the most important and least recognized need of the human soul" (quoted in Said 183), the Chagossians' struggle to recuperate their identity is necessarily entangled in the collective narrative of the myth of the empty territory since, in their specific case and due to the singular particularities of their displacement, "home" is a place of no return. Unlike other dislocated communities who may have the opportunity to visit the geographical territory that is acknowledged as their place of "origin," the Chagossian community's irretrievable loss is experienced as a lack of geographical continuity which, in a way, enhances the mythification of the land -the empty territory- as edenic. ${ }^{7}$

The dangers of conceptualizing Chagos as a paradisiacal Eden results in an erasure, as Laura Jeffery notes, of the hardships of daily life. As an example of the romanticizing process of the collective narrative, Jeffery notices how the sega songs -an indisputable Chagossian cultural marker- performed by islanders resident in the archipelago described in a realistic tone the sorrows and joys of everyday life, whereas the sega songs created after displacement focus entirely on reproducing the

${ }^{7}$ As mentioned before, a selected group of Chagossians were permitted to visit Diego Garcia in 2006. However, the visit was very brief and they were under severe constraints from the US authorities, for example, they could not take photographs and so, their cameras were confiscated. 
nostalgia that assails those excised from paradise. As a matter of fact, the song that initiates this article, "Mo tie ena 13 an" (I was thirteen), corroborates Jeffery's remark. However, the detrimental consequences of integrating this collective narrative as an intrinsic part of one's own individual experience are to be observed in the 2003 court case in the UK in which Mr Justice Ouseley ruled out against the Chagossians because, according to him, all witnesses appropriated the same standardized history of victimhood, to the extent that they provided contradictory statements related to their own experiences of displacement, something that legal language could not possibly sustain. Jeffery's analysis of this specific court case reveals how the collective experience blends with the individual one and pinpoints the potentially dangerous outcome of such conflation when what is called forth is the individual narration. In relation to Chagossians' memories of life on Chagos, the displacement, and their circumstances on arrival in Mauritius, people now remember not the events themselves but their own and others' narratives of the events; they know the significance of what happened to the community, but the ability to recall precise episodes from up to forty years ago has faded over time (Jeffery 2007, 963-964). But the inability to "recall precise episodes from up to forty years ago" does not mean that their present experience of exile and trauma cannot count as evidence of both powerful narrations of resilience and testimonies of existence.

We consider the Chagossian experience as one forged within a trauma paradigm and this constituted the focus of our creative writing workshop. At the core of the traumatic experience there resides a space shared by both the individual and the collective since, as Gilmore puts it, "trauma is never exclusively personal, it always exists within complicated histories" (Gilmore 31). Acknowledging trauma as that which resists linguistic expression (Caruth 1996; LaCapra 2001), our creative writing workshop generated a space wherein an exploration of the intersections of the individual story with the collective one was granted; we were particularly interested in assessing how the profound sense of community that binds the Chagossian experience was formulated upon the loss of their homeland. We likewise sought to untangle the diverse modes of coercion and persuasion that a forceful communal self can inflict upon the marginalized individual. As mentioned earlier, the myth of the empty territory functions as a survival tool that allows Chagossians to be strategically rooted in their homeland and yet, the same myth is a constant reminder of a past that has lost grip of the actual events and given way to a communal narrative that propels Chagossians constantly back to an overpowering narrative of the past that could potentially shun the creation of possible narrations rooted in the present and blur the multifaceted, diversified scenarios of identity-making in the future.

The first-hand experience of trauma that moulds the lives of first generation displaced Chagossians is bound to differ from the traumatic experience of dislocation that second and third generation Chagossians have inherited from their elders. This differentiation between first-hand and inherited trauma is not intended to minimize the traumatic dimension of second and third generation Chagossians, but rather, to highlight a narrative development in the Chagossian experience that, without disclaiming its collective narration manages to delineate a unique, personal story. Hence, the participants -9 women and 3 men- were of different ages to ensure 
an intergenerational dialectics and they were all, from their varied perspectives, motivated to record their memories.

The Chagossians who have remained in Mauritius tend to be people who have only received primary school education and have a limited command of English, which was challenging for us as we were used to running this kind of creative writing workshop with university students and graduates fluent in English. Some of the participants -the younger ones- had an acceptable level of English and were even willing to write their responses in English. Their native language, Mauritian Kreol, is the language that Chagossians and the majority of Mauritians habitually use, despite the fact that English, together with French, are the accepted official languages of the country. ${ }^{8}$ The language difficulty was overcome as the participants could follow our instructions and whenever they stumbled over a particular phrase, Dr. Farhad Khoyratty and one of his doctoral students, Ms. Maxine Ahlan-Yin Corral, from the University of Mauritius came to our aid. We encouraged the participants to write their responses in the language they felt most comfortable in as the purpose of a creative writing workshop is none other than fomenting the ability to express oneself in the language of one's choice. The sessions were conducted in English but Kreol was used by the participants whenever they felt they needed to respond orally to our prompts. On the blog entitled "When the Island Was Sold" that we have published, the responses appear in both Kreol and the English translation.'

The workshop lasted for three very intensive days as in such a short time we were able to accomplish two vital goals. First and foremost, the men and women who attended understood that their culture was being valued by people from outside their community. Secondly, their memories would be published online and thus become visible to a potential worldwide audience. ${ }^{10}$ In short, they were ensured that their life stories were meaningful and valuable.

The methodology we employed to conduct the workshop was geared by the capacity of literature to foment empathy. As literature teachers, we have witnessed the power of literary aesthetics to engage students emotionally and ethically with the representation of reality exposed in written and/or visual texts. Although we were aware of the fact that our participants were not students of literature and that some of them could barely read or write, we nonetheless used a literary aesthetics approach in our sessions. We were extremely sensitive towards the fact that some of the participants were among the original deportees who had limited literacy and so, we adapted conscientiously the texts to this reality, often shortening them and accompanying them with visual material that helped to convey the message in an uncomplicated manner-we used powerpoint presentations that included short texts

${ }^{8}$ According to its Constitution Mauritius in fact does not have any official language even though Kreol is spoken by $90 \%$ of the population. English is the language of administration while French that of culture.

9 See https://blogs.uab.cat/whentheislandwassold/.

${ }_{10}$ The participants in the workshop expressed their consent to have their names appear on the blog, which indicates their eagerness for their stories to be heard and read as authentic. 
and images. We believe it is important to emphasize that limited literacy does not in the least impair cognitive richness and aesthetic sensitivity and, as a matter of fact, the older members of the group were the most articulate in recounting their life experiences. The moment they sensed that their life stories were treasured, they generously shared their experiences with us. What is more, in a conjoined communal effort, their stories were actually written down by the younger participants.

The three sessions were structured around the following themes: (1) Names and Homes, (2) Land, Sea, Borders, Travels, Exile and, finally, (3) Remembrances, History Box. As can be elucidated from the titles of each session, the themes touched upon crucial aspects of the Chagossians' traumatic experiences. Each session was carefully crafted to motivate them to work through their traumas (LaCapra 21-22) so as to reflect on their suffering and thus enable them to act upon these traumatic events productively. We usually started with a seemingly innocent questionnaire to gradually motion them towards the core of the traumatic event via a literary text that exposed some issues concurrent with the Chagossian experience of displacement.

The very simple question "What is your name?" functions as a stepping stone to reach more intimate information about oneself when this question is placed alongside two related questions: "Who gave you your name and why?" and "Where and when were you born?" Thus, in this first session, we managed to unite "names" with "home" since behind each name there is surely a family story about genealogical continuation or discontinuation tightly linked with a sense of "home." This was illustrated through a passage from the novel Love Marriage by the Canadian-SriLankan author, V.V. Ganeshananthan in which the narrator, Yalini, reflects upon her name. Born in Canada of Sri Lankan parents, her name is an attempt on the part of their parents to assuage the disturbing pain of displacement they must endure in Toronto. Their daughter's name becomes their permanent attachment to their homeland.

My parents named me Yalini, after the part of their home that they loved the most. It is a Tamil name, with a Tamil home: a name that means, in part, Jaffna, Sri Lanka, the place from which they came (Ganeshananthan 21)

The idea behind posing "names" and "home" as our first topics was clearly to question to what extent the Chagossians could regard Mauritius as their home bearing in mind the initial -and perhaps continued- rejection of the exiles as undesirable migrants. To enhance the fragmented identity they had to face in Mauritius, they were confronted with a passage from Sandra Cisneros' The House on Mango Street in which the protagonist, Esperanza, must wrestle between the Spanish she speaks at home with her family -the parents are from Mexico- and the English she speaks at school since she lives in the US. The protagonist of Cisneros' novel must negotiate her hybrid identity, her cultural roots spreading across the US and Mexico, her untranslatable Spanish name a constant reminder of her Mexican ancestry. Via the fictional character of Esperanza, our participants pondered on their own hybridity and what they envisioned as their true home. Whereas the older participants did not recognize Mauritius as "home," the younger participants 
deployed a closer Mauritian affiliation. To finish the session with an optimistic note, we resorted to a section from Grace Nichols' poem "Wherever I hang" in which she unabashedly affirms that "Wherever I hang me knickers -that's my home" (3) thus exhibiting "home" as a fluctuating and adjustable concept whose stability is contingent upon geopolitical sensibilities.

The second session opened with images of the 2015 refugee crisis. Shameful pictures of people fleeing poverty, religious and/or political persecution captured the attention of the older participants who relived their own unceremonious banishment from the Chagos Islands. Vivid moments of deportation scenes were recreated by those participants who experienced the traumatic homeland displacement at first hand. Two episodes recalled by Yaya, one of the oldest participants, have been selected to reproduce that fateful moment since, we believe, they are rueful testimonies of the cruelty of humankind in the face of power relations. The first one relates to the anguish she -and they all felt- when all of their dogs were gassed before their very eyes and thought that their children would be next in line. That is the moment, she conceded, when they understood that they had to agree to leave otherwise their children would be killed. The second episode is particularly alluring in its combination of domesticity and forced displacement. Just the day before, the laundry had been done and the clothes lay spread out on stones to let the sun dry them; it was while on board the ship that took them to Mauritius that she suddenly remembered about the clothes and realized then how they would remain there for ever, laying on the sun, forgotten and abandoned, a reflection of their own fate. And yet, the Chagos Islands would perennially remain with them, their children and their grandchildren. This is what the poem "Voyager Dust" by Syrian-American Mohja Kahf showed them, how "voyagers" always "carry it on their shoulders, I the dusting of the sky they left behind" (1). As the American-transplanted Mohja Kahf realizes, the voyager's dust that impregnated her mother's scarves is now on her shoulders too, a poetic recognition of inter-generational communion.

While preparing this session, we knew we had to be extremely tactful in the way we presented the material and how we could manage the posterior discussion. The reason for this is the knowledge that the Chagossians, as mentioned before and unlike other displaced individuals, cannot return to their islands because of the presence of the American military base. It is true that a select group of Chagossians, among them some of our participants, was permitted to visit the island in 2006 but that was regarded as a pilgrimage and were not allowed to take anything from the islands, not even sand from the beach. ${ }^{11}$

Jisele, one of the participants who went on this pilgrimage, shared with us how distressed she was before the sight of her parents' neglected grave which was located next to the immaculately tended grave of a dog that had belonged to one of the Americans living in the military base. The right to mourn your loved ones

${ }^{11}$ Needless to say, and as the objects they brought to our last session testified to, they disobeyed and took with them sand and conch shells they picked up from the beach. 
is not equally granted to all human beings, as Judith Butler insidiously observes in Precarious Life and the Chagos Islanders' experience of exclusion crudely testifies to.

A passage from Abdulrazak Gurnah's 2001 novel By the Sea was the starting point for our third session which was devoted to remembrances. In this extract, the protagonist, sixty-two-year-old Saleh Omar, is humiliated by the customs officer at Gatwick airport who, in a theatrically exaggerated manner, displays the meagre contents of his suitcase and confiscates the only valuable possession he took with him from Zanzibar: a small casquet containing the perfume ud-al-qamari. As it is, ud-alqamari is his emotional link with his homeland, which he is obliged to leave for fear of his life. When Kevin Edelman, the customs officer at Gatwick, dispossesses Saleh Omar from his precious object, this is felt as a theft, as an illegal act sanctioned by the law, and this is exactly the way that our participants interpreted the scene and connected it with the theft of the Chagos Islands. We think it is worth reproducing the whole passage:

'What's this?' he asked, then carefully sniffed the open casket. It was hardly necessary, as the little room had filled with glorious perfume as soon as he opened the box. [...] So I didn't tell him that it was ud-al-qamari of the best quality, all that remained of a consignment I had acquired more than thirty years ago, and which I could not bear to leave behind when I set out on this journey into a new life. When I looked up again I saw that he would steal it from me.

Ud-al-qamari: its fragrance comes back to me at odd times, unexpectedly, like a fragment of a voice or the memory of my beloved's arm on my neck (Gurnah 13 \& 14)

The historical, emotional and cultural import attached to the wooden casquet of $u d$-al-qamari led us to request the participants to bring any objects that they regarded as part of their history to form part of what we called the history box. The rationale behind this exercise was that these objects could be placed within a box and could be sent to outer space as an example of their culture so if any human being opened the box they would have an idea of what this culture meant for humanity. Among the objects that the participants chose for the history box were sand and shells from the islands, conscientiously preserved by the older members of the group, which they had collected on the pilgrimage trip mentioned above deliberately contravening the regulations enforced by the administrative organs that authorised the pilgrimage. The younger members of the group suggested putting a fishing rod in the box as a reminder of the profession of many of the inhabitants of the islands. The bomme and the zeze, musical instruments used in sega singing and dancing, were also considered to represent their culture and the inclusion of a piké, a tool used to cut up coconuts, indicated the widespread use of the fruit in their cuisine as well as a tribute to the major export and source of livelihood of the archipelago.

Creative writing has proved an invaluable tool to bear witness to trauma. As a tool of disclosure and safe expression (Jess-Cooke 11), creative writing is therapeutic because it enhances creative expression which is an inextricable part of our subjectivity. The creative process that culminates in the production of a piece 
of work is in itself a useful, meaningful act that communicates an experience that engages or relates to other people. Therefore, the act of remembering and writing their experiences worked as a great therapy for building up self-esteem as a people and for claiming a space, as Chagossians, in the Indian Ocean imaginary. By communicating their own individual stories, by processing individually the collective memory that shaped their communal selves, in short, by owning and expressing their traumatic experiences, the Chagossian participants of our creative writing workshop were able to disclose and interrogate those silences that are imbricated in the narration of the empty territory and perilously plunges them into a transcendental homelessness.

The ultimate aim of this creative writing workshop was to grant visibility to the Chagossian fight for identity and recognition. Moreover, as is often the case, ultimate aims are forged within a poignant desire to express that which lies beyond expression because, as Jisele, one of the participants in the workshop revealed in a terrifyingly genuine declaration of emotional incapacity, "It hurts." In this simple albeit not simplistic "It hurts" resided the essence of a successful creative writing methodology: to create a space wherein participants whose existence is enveloped by the persistent and overwhelming shadow of trauma can find a way to articulate their frustrations, their desires, their longings and, above all, their stubbornly human claim to existence. In an act of exceptional generosity, Monette thanked us for helping them verbalize emotions that were kept inside themselves because they were too harrowing to be let out and shared with others. As far as we are concerned, and in what attempts to be an act of profound admiration, we would like to conclude this article by overtly thanking all the participants in the workshop and, above all, for giving us an invaluable lesson in human dignity.

Reviews sent to author: $22 / 12 / 2020$

Revised paper accepted for publication: 02/02/2021 


\section{WORKS CITED}

Allen, Stephen. The Chagos Islanders and International Law. Hart Publishing, 2014.

Butler, Judith. Precarious Life: The Power of Mourning and Violence. Verso Books, 2004.

Caruth, Cathy. Unclaimed Experience. Trauma, Narrative, and History. Johns Hopkins University Press, 1996.

Chan Low, Jocelyn. "The Making of the British Indian Ocean Territory: A Forgotten Tragedy." The Western Indian Ocean. Essays on Islands and Islanders. Shawkat M. Toorawa (Ed.). The Hassam Toorawa Trust, 2007. 105-126.

Cisneros, Sandra. The House on Mango Street. Vintage, 1983.

Curtis, Mark. Web of Deceit. Britain's Real Role in the World. Vintage, 2007.

CurTis, Mark. http://markcurtis.info/2018/01/27/mauritius-declassified/.

DAvis, Heather, and Zoe Todd. "On the Importance of a Date or, Decolonizing the Anthropocene." ACME. An International Journal for Critical Geographies. 16/4 (2017): 761-780.

De L'Estrac, Jean Claude. Next Year in Diego Garcia... Translated by Touria Prayag. Elp Publications, 2011.

Ganeshananthan, V.V. Love Marriage. W\&N, 2009.

Gilmore, Leigh, The Limits of Autobiography. Trauma and Testimony, Cornell University Press, 2001.

Group Tanbour Chagos. Leritaz Kiltir Chagossien. Chagos Refugees Group and University of Edinburgh, 2018.

GurnaH, Abdulrazak, By the Sea, Bloomsbury, 2001.

Jeffery, Laura. "Victims and Patrons: Strategic Alliances and the Anti-Politics of Victimhood among Displaced Chagossians and their Supporters." History and Anthropology $17 / 4$ (2006): 297-312.

Jeffery, Laura. "How a Plantation Became Paradise: Changing Representations of the Homeland among Displaced Chagos Islanders." Journal of the Royal Anthropological Institute 13/4 (2007): 951-968.

Jeffery, Laura. "Forced Displacement, Onward Migration and Reformulations of 'Home' by Chagossians in Crawley, UK." Journal of Ethnic and Migration Studies 36/7 August (2010): 10991117.

Jefferr, Laura, and David Vine. "Sorrow, Sadness, and Impoverishment: The Lives of Chagossians in Mauritius." Eviction from the Chagos Islands: Displacement and Struggle for Identity against Two World Powers. Sandra Evers \& Marry Kooy (Eds.). Brill, 2011. 83-102.

Jess-Cooke, Carolyn. In/Visible Traumas: Healing, Loving, Writing. Femrite. Uganda Women Writers Association, 2019.

Johannessen, Steffen F. "From Socialist Uprising to Cultural Genocide: The Emergence of Traditions in Chagossian Struggles for Repatriation." Tradition Within and Beyond the Framework of Invention: Case Studies from Mascarenes and Japan. Susanne Klien and Patrick Neveling (Eds.). Zentrum für Interdisziplinäre Regionalstudien Vorderer Orient, Afrika, Asien der Martin-Luther-Universität Halle-Wittenberg, 2010. 69-104. 
Johannessen, Steffen F. "Cleaning for the Dead: the Chagossian Pilgrimage to their Homeland." Eviction from the Chagos Islands: Displacement and Struggle for Identity against Two World Powers. Sandra Evers and Marry Kooy (Eds.). Brill, 2011. 183-217.

Johannessen, Steffen F. "Dis/Entangled Hubs: Connectivity and Disconnections in the Chagos Archipelago." Connectivity in Motion. Island Hubs in the Indian Ocean World. Burkhard Schnepel and Edward A. Alpers (Eds.). Palgrave Macmillan, 2018. 259-287.

KaHF, Mohja. E-mails from Scheherazad. University Press of Florida, 2003.

Lacapra, Dominick. Writing History, Writing Trauma. Johns Hopkins University Press, 2001.

Loвo, Jessica. "The Chagos Marine Protected Area: A Whole Kettle of Fish.” QMHRR Queen Mary Human Rights Review 3/ 1 (2016): 10-32.

Nichols, Grace, “Wherever I hang”, Kunapipi, 20/1, 1998. 3. https://ro.uow.edu.au/kunapipi/ vol20/iss1/5.

Pilger, John and Chris Martin. Stealing a Nation Granada Productions for ITV, 2004. http:// www.johnpilger.com.

Ravi, Srilata. "Grieving Islands: History, Memory and the Chagossian Tragedy". Eyes Across the Water: Navigating the Indian Ocean, Pamila Gupta, Isabel Hofmeyr \& Michael Pearson (Eds.). UNISA Press, 2010. 344-360

RInCON, Paul. "UK sets up Chagos Islands marine reserve”, BBC 1 April 2010. http://news.bbc. co.uk/2/hi/science/nature/8599125.stm.

SAID, Edward, "Reflections on Exile." Reflections on Exile and Other Literary and Cultural Essays. Penguin Books, 2001.

SAnd, Peter H. "Diego Garcia: British-American Legal Black Hole in the Indian Ocean?" Journal of Environmental Law 21/ 1 (2009): 113-137. 